\title{
Irakasle ofizioa ikasten: Practicumaren esperientzia
}

\author{
Learning teachers' profession: the Practicum experience \\ Itziar Iriondo*1, Itziar Plazaola ${ }^{2}$, Teresa Zulaika ${ }^{1}$ \\ ${ }^{1}$ Hezkuntza, Filosofia eta Antropologia Fakultatea (UPV/EHU) \\ ${ }^{2}$ Genevako Unibertsitatea
}

LABURPENA: Irakaslegaiak hizkuntzaren irakaskuntzan trebatzeko antolatutako prestakuntza inguramenduaren ikerketaz arituko gara artikulu honetan. Lana bideo-formazioaren esparruan kokatzen da, jardueraren azterketa izeneko prestakuntza eta ikerketa korrontean. Practicumaren esperientzia du aztergune. Irakasle hasiberriak aditu bihurtzeko garatu behar duen ibilbidea ezagutzeak elkarlotutako fenomenoen konplexutasunera garamatza. Artikuluan zehar azpimarratuko dira hasiberriaren jardueraren berariazkotasuna, horren prestakuntzaren garapena, hizkuntzaren didaktikarekin lotutako jarduera tipiko bat eta eskolaren eta unibertsitatearen arteko hitzarmen beharra.

GAKO-HITZAK: irakasleen prestakuntza, jardueraren azterketa, autobehaketa, prestakuntza inguramendua, Practicumaren esperientzia.

\begin{abstract}
This paper presents the results of a research study focusing on a training environment designed to foster the teaching skills of novice teachers. The study is located within the field of videobased training, which in turn forms part of the research and training approach known as activity analysis. The focus of study is a teaching Practicum. Identifying the process through which novice teachers must go to become expert teachers leads us to explore a highly complex and interlinked series of phenomena. The paper will highlight the specific characteristics of novice teachers' activity, the development of their training, one typical activity linked to language teaching and the need for collaboration agreements between schools and universities.
\end{abstract}

KEYWORDS: teacher education, activity analysis, self-confrontation, work environment, Practicum.

* Harremanetan jartzeko / Corresponding author: Itziar Iriondo. UPV/EHU. Hizkuntzaren eta Literaturaren Didaktika. Hezkuntza, Filosofia eta Antropologia Fakultatea. Tolosa hiribidea, 70. E-20018 Donostia/San Sebastián - itziar.iriondo@ehu.eus http://orcid.org/0000-0001-8038-4910

Nola aipatu / How to cite: Iriondo, Itziar; Plazaola, Itziar; Zulaika, Teresa. (2018). «Irakasle ofizioa ikasten: Practicumaren esperientzia»; Tantak, 30(2), 117-151. (https://doi.org/10.1387/tantak.19778).

Jasotze-data: 2018/06/12; Onartze-data: 2018/09/21

ISSN 0214-9753 - elSSN 2444-3581 / (c) 2018 UPV/EHU

(c) (i) Obra hau Creative Commons Atribución 4.0 Internacional-en

lizentziapean dago 


\section{SARRERA}

Irakaskuntzarako prestatzea helburu duen formakuntzaz arituko gara artikulu honetan. Irakasle hasiberrien Practicum eta Gradu Amaierako Lana lotzen dituen esperientziaren berri emateaz gain, formakuntza-prozesuaren inguruko berrikuntza-proposamena azalduko dugu. Nola jokatzen du irakasle hasiberriak gelako saioaren aurrean? Zein dira jarduteko onuragarri gertatzen zaizkion baliabideak? Zein bere jardueraren esanahia? Zerk lagunduko luke bere jarduera hobetzen?

Aurkezten dugun prestakuntza iker-egitasmo baten ataletako bat da. Proiektu horren helburu nagusia hau da: irakaskuntza ofizioa ikasteko, batik bat hizkuntzen irakaskuntzarako, prestaketa metodo aproposak sortzea eta ikerketaren bidez horien balioa baieztatzea eta hobetzea.

Lan hau prestakuntzaren inguramenduak ikertzen dituen esparruan kokatzen da. Horrelako ikerketak oinarritzen dira, alde batetik, ergonomia kognitiboko lanetan (Durand, 2008; Clot eta lag. 2001) eta, bestetik, oro har, bideo-formakuntza deitzen diren hasierako nahiz etengabeko prestakuntzetan eta horien ikerketetan (Gaudin \& Chaliès, 2012; Hatch \& Grossman, 2009; Lussi Borer eta lag., 2014; Picard, 2014; Santagata \& Yeh, 2015; Seidel eta lag., 2011; Sherin, 2001; van Es \& Sherin, 2008). Prestakuntzaren ikerketa esparru zabalean, lan jarduera jomuga duen korrontea da lan honen azpiatala.

Irakasleen prestakuntzak planteatzen duen erronka ofizioaz jabetzea da, profesionalizazioaren eraikuntza. Urteetan, eskola arloetako diziplina ezagutzak eta pedagogiaren emaitzak iturri nagusitzat hartu dira, baina orientabide horrek bere mugak ditu, ofizioa praktikarekin bakarrik eskuratzen baita. Irakasle berriak irakaskuntza lanera azkar ohitzeak indar eta orientabide berrituak eskatzen ditu. Artikulu honetan azalduko dira, alde batetik, giza jarduera aztergai duten orientabide teorikoak eta horietan oinarritutako tresna metodologikoak prozesu horretan lagungarri gerta daitezkeelakoan; bestetik, esperientzia baten berri emango da; bukatzeko, ondorioen interpretazioak prestakuntzarako eskaintzen dituen giltzarriak azalduko dira.

\section{GIZA JARDUERA AZTERGAI: ORIENTABIDE TEORIKOA}

Azken urteotan, jarduera, lana, praktika aztertzen dituzten ikerketa korronteak zabaldu dira Giza eta Gizarte Zientzietan izaniko bira pragmatikoak bultzatuta. Orientabide hauek Hezkuntza eta Prestakuntza Zientzien berrikuntzan eragin handia izan dute. Ikerketa gerturatze horietan oinarrituz, helburu hau finkatu dugu: lan saioak, gure kasuan irakasle berriak Practicum garaian egindakoak, aztertzea.

Irakasle lanaren azterketan diharduten ikertaldeek, bira pragmatikoarekin bat etorri arren, badituzte teoria ñabardura ezberdinak, horien artean: 
Schützen gizarte-ekintzaren teoria, Deweyren pragmatismoa, Varelaren enakzio teoria eta filosofiako eta psikologiako eskola errusiarraren jarduera teoriak (Bajtin, Vygotsky).

Schützek (1932) (Blin, 1999) garatzen duen teoriak esperientziaz eta haren esanahiaz dihardu; horregatik, funtsezkoak dira gure ikerketarako. Azter ditzagun alderdi garrantzitsuenak.

Schützek dio egileak tipoen bidez hautematen dituela egoerak. Tipo horiek pertzepzio moduetan gorpuzten dira, hain zuzen ere, iritzietan eta gizarte-ingurunearen, familiaren, eskolaren eta abarren bidez helarazten direnetan. Hizkuntzak paper nagusia du transmisio honetan; jardueraz aritzeko semantika dugu adibiderik argiena: egilea, egoera, intentzioa, eta abar. Kategoria horiek ezaugarritzen dute jarduera tipoa, eta beraz, hitz horiek gabe ezin dugu jardueraz hitz egin; (Ricoeur, 1977). Bestetik, tipoek ohiko jarduera-egoerak konpontzeko soluzio tipikoak eskaintzen dituzte (Cefaï, 1994).

Zertan eta nola laguntzen dute tipoek jardute horretan? Egoera zehatzaren aurrean, egileak iraganerako itzulera egiten du islatze prozesu bati esker, hala, egin dituen jardueren artetik, antzekoren bat identifikatzen du. Horrek laguntzen dio jakiten zein jarduera-tipoa den aurrean duen egoera berria. Egilea baliatzen da eskura dituen tipoez (bere arloan ohikoak direnez) eta, baita ere, bere bizitzan pilatutako esperientziez. Irakaslearen kasuan, eskola ematea, aritmetikako problemak ebaztea, taldean abestea, jakintza-gaia azaltzea, eta abar dira eskola inguramenduko jarduera tipoen adibideak. Irakasle jakin batek erabil dezake, baita ere, beste zenbait esperientzia, adibidez: udalekuetan begirale izan zenekoak.

Burututako jarduerak gogoratzeak ahalbidetzen du egoera berri baten aurrean esperientzia «berriro-hartze» hori. Baina jarduteko erak ez dira modu mekanikoan berrartzen. Edozein jarduera-egoeraren aurrean, egileak joan-etorriak eta moldaketak egin behar ditu aldez aurreko esperientzien ezaugarrietatik egoera berriaren ezaugarrietara; horrela, egoera berria zehaztuz doa. Joan-etorri horiek dira tipifikazioak. Beraz, kokatutako kognizio-ekintzari eta ergonomia kognitiboari jarraituz, (De Montmollin, 1986; Salembier, Theureau, Zouinar \& Vermersch, 2001; Suchmann, 1987) jardueraren eredu arrazional hutsa ez dugu egokitzat jotzen. Horregatik, lanean eta irakaskuntzan ere, ez zaigu aproposa iruditzen postulatzea irakaskuntza aldatzeko nahikoa dela preskripzioak (programa, eskola liburuak, fitxak) berritzea, preskribatutako eredu horiek eragin mugatua baitute egilearen jardunean.

Ikuspegi teoriko honek azpimarratzen du egileak burututako jardueren eta horien esanahien garrantzia. Bestetik, ideia hau nabarmendu nahi genuke: egilearen esperientzia «aurrepredikatiboa» da, alegia, berau kontatu ala deskribatu aurretikoa. 
Itziar Iriondo, Itziar Plazaola, Teresa Zulaika

\section{EGILEAREN ESPERIENTZIA EZAGUTZEKO TRESNA METODOLOGIKOAK}

Bi dira irakaslegaiaren jarduera aztertzeko, proposatzen ditugun metodoen helburu nagusiak: jardueraren aztarnak sortzea eta gune egokiak eskaintzea egileak horien analisia egin dezan. Horretarako aukeratu da, beste hainbat daturen bilketaz gain, (prestakuntzan sortutako dokumentuak, eginiko saioak, eta abar), konfrontazio metodoak erabiltzea: autobehaketa, autobehaketa gurutzatua eta talde-behaketa. Metodologia horiek aukera ematen dute jarduerarekin lotutako esanahiak ekoizteko. Egilearen esperientziak eta esperientzia hori hitzez adierazteak laguntzen dute esperientzia plazaratzen eta garatzen. Tresna horiek ikerketa tresnak dira, egilearen esperientzia ezagutaraztea bideratzen dute eta egoera jakin batzuetan prestakuntza tresna ere bihurtzen dira. Hori da prestakuntza ikertzen duen lan honetan metodologiaren giltzarria.

Erabiltzen ditugun konfrontazio-metodoak ergonomia kognitiboa oinarri duten bi korrontek garatu dituzte. Bata, «Ikerketa teknologikoaren programa» da (Durand, 2008; Theureau, 2010). Jarduera errealaren ulermena eta analisia oinarritzat hartuz, prestakuntzarako dispositiboak sortzea proposatzen du. Besteak, «Jardueraren klinika» (Clot, 2001) du izena; Vygotskyren eta Bajtinen mintzaira jardueraren psikologiaren kontzeptuetan oinarrituta dago.

Gure orientabidean hizkuntza eraikitzaile, forma-sortzaile denetik ari gara. Berbaldian egilea tipifikatzen ari da burututako jarduera: nola egin duen, zer ariketa mota zen, zer-nolakoa izan den bere bilakaera, zein ziren partaideak eta haien jarduerak, eta abar. (Alonso eta lag., 2017); Plazaola eta lag., 2014; Plazaola \& Stroumza, 2007; Plazaola \& Ozaeta, 2014). Autobehaketa prestakuntza eta ikerketa-metodo moduan erabiltzeak ezaugarri bereziak hartzen ditu: ikasgelan egiten den bideo-grabazioa beranduagoko autobehaketaren oinarria da. Ikertzaileak lortu behar du egileak bere aurrean duen jarduera arakatzea. Horretarako kontsigna argia ematea komeni da egileak bere burua gelako une hartan bertan koka dezan. Irakaskuntzari buruzko gogoeta orokorrak saihestu nahi dira, egilea saia dadin ikasgelan egindako esperientzia jakin hori diskurtso forman jartzen. Proposatzen da gertatutakoaren analisi xehetua egitea. Egilearen eta ikertzailearen arteko elkarrizketa hau ez da ohikoa; helburua egilearen ikuspuntutik gelan bertan gertatutakoa ulertzea da; beraz, berbaldia ez da erabat antolatuta egongo, ikertzaileak ez dio aldez aurretik prestatutako gidoi bati jarraituko.

Autobehaketa gune egokian, giro erosoan egin behar da; horrela, egilea errazago murgilduko da bere jardueran, hobeto sortuko du une horretako hizkerak eskatzen dion hitz egiteko era egoki hori, zeina aldez aurretik prestatu ez den. Elkarrizketa mota honi Merleau Ponty-k «berbaldi eraginkorra» deitzen dio (Richir, 1988); horrela, egilea saiatzen da hel- 
buru bat lortzen benetan hori zertan datzan jakin gabe eta moldatzen du bere berbaldia esaten duena esan nahi duenarekin alderatuz. Prozesu horrek ahalbidetzen du tipifikazioen garapena: egindakoa azalduz, egindakoaren esanahietan sakontzen da, mugak argitzen dira eta hobekuntzak irudika daitezke.

Marko honetatik, autobehaketa tresna transformatzailea dela defendatzen dugu. Horren bidez, egileak bere esperientzia azaleratzen du eta, horrela, esperientzia hori aldatzeko eta garatzeko aukerak sortzen ditu.

\section{PRESTAKUNTZAREN INGURAMENDUA}

\subsection{Esperientzia pilotua}

Azalduko dugun prestakuntzaren hastapenak 2012-2013 ikasturteko esperientzian aurki ditzakegu. Ikasturte horretan hasi ginen aplikatzen ordura arte Practicumaren prestakuntzarako erabiltzen ziren grabaketak, gure eginez ikerkuntzarako baliagarri bihurtu zitekeen metodologiaren eta jardueraren analisiaren orientabidea.

Esperientzia-pilotu modura, boluntario gisa aurkeztutako hiru ikasleri egin zitzaien proposamen hau: aurrez aurreko elkarrizketak egin zitzaten Practicumerako prestatutako eta grabatutako saio baten inguruan, aipaturiko orientabideari jarraituz.

Lehen saiakera horietatik, hainbat irakaspen jaso genuen, hala nola, nolako zailtasunak dituen hasiberriak mahai-jokoa bezalako jarduera klasikoa antolatzean, atzerrriko hizkuntza lantzeko (Plazaola \& Iriondo, 2014); ikertzailearen paperaren garrantzia (ondorioztatu ahal izan zen elkarrizketetan, irakasle hasiberriak argi izan behar lukeela ebaluazio eta araurik jasoko ez duela, eta, era berean, ikertzaileak, galdera zuzenak eta gaitzespenak saihesten saiatu beharko duela (Ruiz Bikandi \& Plazaola, 2012).

Aurkeztutako grabaketetan, hasiberriek irakaskuntzari buruz zuten ikuspegi eta asmo guztien erakustaldi-kutsua nabari zen; agerian geratu zen irakasleari jarduera «enblematikoak» erakutsi beharra zela nagusi ikasleen iritziz. Saio bakarra prestatu eta grabatzeak eragindako uste hori zuzentzeko, aurrerantzean, jarduerak maiz diseinatu eta grabatzea aholkatu zitzaien hasiberriei, gure helburua ohiko irakats-jarduerak aztertzea baitzen.

Esperientzia pilotu honi esker ikusi ahal izan zen:

1. Bideo-formakuntzaren abantaila ikasleen jarduera ikuspegi ezberdinetatik aztertzeko (Zulaika \& Iriondo, 2015).

2. Ikertzailearen rolaren eragina ikaslearen berbaldian.

3. Irakasle-ofizioaren garapenerako zein garrantzi handia duten jardueraren beraren azterketek eta hausnarketek. 
Practicum-ikasleek beren jardueraren aurrean egindako autobehaketez gain, ikertzaile berarekin kide baten grabaketaz ere izan zuten elkarrizketa, eta, azkenik, irakasle adituek ere, irakasle hasiberrien saioak ikusi eta aztertu zituzten.

Material hori izan zen hurrengo ikasturteetan erabili zen «Sarrera modulua» izendatutako prestakuntza-ikerkuntza prozesuaren oinarria. Horrela, Practicumera joan aurretik, hasiberriak metodologia horretan trebatzeko tresna bihurtu ziren fase honetako zenbait grabaketa sekuentzia. «Sarrera modulu» horren inguruan antolatutako lehen mintegiak ere bideoz jaso ziren ikerkuntzarako corpusaren atal gisa.

\subsection{Ikertutako prestakuntzaren inguramendua}

Lan honetan aurkezten dugu 2013-2014 eta 2014-2015 ikasturteetan Euskal Herriko Unibertsitateko Hezkuntza, Filosofia eta Antropologia Fakultatean egindako prestakuntza bat. Proiektu honek lotzen ditu Haur Hezkuntzako eta Lehen Hezkuntzako Graduetako laugarren mailako Practicuma (aurrerantzean PIII) eta Gradu Amaierako Lana (aurrerantzean GRAL) ikasleak bere irakats jarduerari buruz egin behar duen gogoetaren bidez. PIIIaren helburu nagusiak hauek dira: heziketa-prozesua bere osotasunean bizitzea eta prozesu horrekin zerikusia duen ororen inguruan gogoeta egitea. «Practicuma, beraz, heziketa-ibilbidean guztiz txertatuta agertuko zaigu, ikaskuntzarako adierazgarri eta kontrasterako iturri gisa. Halaber, praktikak zentzua ematen die horren euskarri diren eta horien bilakaera orientatu dezaketen ezagutza teorikoei» (Ormazuri et al., 2013). Hiru ardatz nagusi ditu PIIIak, eskola batean irakasle-lana behatu, horretan jardun eta irakaslegaiak bere lanaren inguruan hausnarketa egitea. Azken honek lotura zuzena du GRALean landuko diren gaiekin.

GRALean, ikasleak, Graduko ikastaldian jasotako prestakuntza gaiak eta lortu dituen ahalmenak, konpetentziak eta trebetasunak bildu eta garatu behar ditu proiektu, memoria edo azterlan original batean. «GRALaren edukiak aukera emango du ikasle bakoitzaren prestakuntza finkatzeko eta bere lanbidea sakonago ezagutzeko» (UPV/EHU, 2015). Ezinbestekotzat jotzen da ofizio honetara egokitzeko, hipotesiak eta zalantzak sortzea eta erantzunbideak bilatzen saiatzeko jarrera aktiboa edukitzea.

Lehen Hezkuntzako eta Haur Hezkuntzako Graduko laugarren mailako 31 ikaslek hartu zuten parte esperientzia honetan; haietako 11 Euskara, Hezkuntzarako Tresna espezialitatekoak ziren eta 20 Atzerriko Hizkuntzakoak. Ikasleek hamabi aste eman zituzten PIIIa egiten hainbat ikastetxetan. Lehen aipaturiko «Sarrera modulua» izan zen abiapuntua esperientzia honetan. 
Praktikaldia hasi baino lehen, unibertsitateko tutoreak (ikertzaileak) gidatutako zenbait mintegi antolatu ziren. Bertan, besteak beste, PIIIko gidaren edukiak eta jardueraren analisian oinarritutako metodologiak jorratu ziren. Halaber, prozesuan zehar erabiliko zen plataforma digitalaren inguruko informazioa helarazi zitzaien irakaslegaiei.

Saio horietan asko azpimarratu zen zertan zetzan egin beharreko bideograbazioa. Lehen esan bezala, esperientzia pilotuaren irakaspenetariko bat izan zen hasiberriei argi adierazi behar zitzaiela grabatu beharreko saioa ez zela inondik inora izan behar graduan zehar eskuratutako gaitasunen erakustaldia. Garbi geratu behar zen eguneroko saio arrunta zela interesgunea. Halaber, hasiberriei gomendatu zitzaien praktikaldian zehar grabazio bat baino gehiago egitea.

Fase honetan, proiektua bere osotasunean argi azaltzeak garrantzi handia zuela egiaztatu zen beranduago: ikertzaileak, hasierako mintegi haietan egindako zenbait bideo-grabazioren bidez konturatu ziren zein garrantzitsua den, batez ere lehenengo urratsetan, konfiantzazko giroa sortzea, hasiberriak bere zalantzak eta kezkak lotsarik gabe kanpora ditzan.

Praktikaldian zehar, ikasleek berek prestatutako eskola-saio bat bideoz grabatu behar izan zuten. Fase horretan ere hasi ziren ikertzaileak proiektuaren bestelako ebidentziak jasotzen. Horien bidez, prozesuaren berri zuzena eduki zitekeen, besteak beste, ibilbidean zehar sortzen ari ziren oztopo eta zalantzak gainditzen laguntzeko.

Hauek izan ziren jasotako ebidentzia horiek: unibertsitateko tutoreak ikastetxeetara egindako bisiten txostenak eta oharrak; foroetako elkarrizketak, lehenengo mintegiko bideo-grabazioak eta gainontzekoetako apunteak; hasiberrien egunerokoak; PIIIko txostenen lehenengo zirriborroak; GRALaren hasierako gidoiak eta hizkuntzaren didaktikari buruzko gaien aukeraketak.

Praktikaldia bukatu ondoren, baina denbora-tarte luzerik pasatzen utzi gabe, unibertsitateko irakasle-tutorearekin hasiberriek autobehaketak burutu zituzten, orduan ere, kameraren aurrean. Zenbait kasutan talde-behaketak ere egin ziren.

Jarduerei buruzko gogoetaren eta analisiaren prozesu hori guztia bihurtu zen GRALaren ardatz. Lan horretan, batez ere, hizkuntzaren didaktikari lotutako gaiei erreparatu zitzaien. Hauek izan ziren zenbait GRALen izenburuak: Catching and holding attention. A self-analysis of a session (Arreta jaso eta mantentzea. Saio baten auto-azterketa); Irakasle hasiberrien prestakuntza bideo-grabaketen bidez: irakurmenaren ulermena; Teacher's language: the key for the foreign language classroom (Irakaslearen hizketa: atzerriko hizkuntzako gelaren giltzarria); Hizkuntza irakaslea izateko nire burua trebatzen: ahozko adierazpena; mapa kontzeptuala. 


\section{IKERKETAREN GALDERAK, CORPUSA, AZTERKETA TRESNAK}

Gorago adierazi dugun bezala, lan honen objektua irakasle hasiberriaren prestakuntzaren bilakaera atzematea da. Horretarako, beren lan saioen «esperientzia» ezagutu beharko dugu, hau da, ikastetxean egin duen hizkuntza irakasteko jarduera tipoa (zer motatakoa den, alegia, irakurketa saioa, deskribapen ekoizpena, kontsignen azalpena gela aurrean, eta abar), horren antolamendua eta garapena nola egin dituen; zernolako ezagutza, jarduera-eredu eta beste izan dituen euskarri ariketa asmatzerakoan eta egiterakoan. Corpuseko material ezberdinetan irakaskuntza-jardueraren sorrera eta bilakaera atzematen saiatuko da ikertzailea; besteak beste, zein izan den jardueraren inguramendua, fisikoa nahiz sinbolikoa, zein irakats-objektua eta programa, zer-nolakoa ikasleen partaidetza.

Ikertzaileak hasiberriaren jarraipena egiten du Practicum garaian. Prozesuaren hainbat ebidentzia biltzen ditu: mintegiak, eskolarako bisitak, foroak, eta abar. Ikasleek egiten dituzten eskola-saioen grabaketek garrantzi nagusia dute. Horrela, hasiberriaren ibilbidea interpretatuz doa ikertzailea, ebidentzia guztien bidez. Behaketa zabal hori da elkarrizketak gidatzeko ikertzaileak duen euskarri nagusia. Izan ere, urtetik urtera ikasleen kezka batzuk maiz errepikatzen dira: nola sustatu haurren artean ahozkotasuna, nola eman jarduera bat egiteko azalpenak, talde-lana eta banakako lana nola antolatu, eta abar.

\subsection{Elkarrizketaren gida eta ikerketa galderak}

Hasiberriak bere saioaren grabaketa behatzen duenean, are gehiago ikertzailearekin ari bada, saioa ebaluatzen diharduela ulertzen du. Inplizituki horrela interpretatzen da gizarte egoera hori. Horregatik bultzatuko da, elkarrizketaren gidan, jardueraren deskribapen xehean, azterketan, aritzea, ebaluazio-justifikazioa ahal den heinean saihestuz. Elkarrizketa erdi-zuzenduaren tankerara, galderen forma sintaktikoak, zergatik? esapidea baztertuko dute ikertzaileek, nola? galderaz ordezkatuz.

Ikertzaileak gogoan dituen gaiak honela sailkatuko ditugu:

a) Nola moldatu duen hasiberriak jarduera. Prestatu al duen ala ez, zer jarduera tipoa den berak eragindakoa. Nondik elikatu duen bere egitasmoa, non inspiratu den. Izan al dituen beste jarduera batzuk erreferentzi modura. Unibertsitatean jasotako ezagutzek jokatzen duten papera jardueraren antolamenduan. Bere motibazio eta asmoak. 
b) Zer gertatu den. Grabaketaren irudietara joz, behar denean horiek geldituz: hemen zer egin duzu? Hor zer gertatzen ari da? Gertaera zehatzetara eramango da hasiberriaren arreta.

c) Nola bizi izan duen; abiatu denean oztoporik aurkitu duen eta horrela gertatu bada, hori saihesteko zer aldaketa egin dituen.

d) Nola ikusten duen bere jarduera hau egin ondoren; grabazioa aurrean duela, nola azaltzen zaion gertatutakoa; nola baloratzen duen egindakoa; zer eragin duen beregan grabaketaren azterketak.

e) Zerk lagunduko liokeen bere interbentzioa hobetze aldera.

Galdera horiek inguratzen dute ikertzailearen egitasmoa; beraz, elkarrizketa ez da galdeketa moduan gidatuko. Ikerketaren orientabide teoriko eta metodologikoen arabera, irakasle hasiberriaren diskurtsoaren bilakaera sustatuko du, grabaketaren aurrean irakaskuntza jarduera arakatzea baitu helburu, ez modu arrazonatu-logiko hutsez, ez zergatik hutsen inguruan.

\subsection{Corpusa}

Lehen aipatu den moduan, bi ikasturteetako ikasleen prestakuntza ibilbidearen aztarnek osatzen dute ikerketaren corpusa. Hauetako zenbait, bideo-grabaketak dira: unibertsitatean ikasleekin egindako mintegiak; hasiberrien eskola-saioak, saio horietako jardueren azterketak (autobehaketa nahiz talde-behaketako elkarrizketak). Beste hainbat, idatziak: ikasleen GRALak eta posterrak; unibertsitateko irakasleak eskoletako bisita saioetan bildutako oharrak, eta abar.

Hiru aztarna mota horietatik, gure ustez, autobehaketak eta talde-behaketako elkarrizketak dira tresnarik eraginkorrenak irakasle-ofizioa bereganatzeko. Beste ebidentziek ikasleen garapenaren datuak eskaintzen dizkiguten arren, elkarrizketetatik hartutakoak dira nagusiki beherago aztertzen diren adibideak. Corpuseko beste dokumentuak Practicumeko gertaeren testuingurua osatzen dute eta ezinbestekoak dira, batik bat, elkarrizketetan esaten denaren zentzua sakon atzemateko.

Ondoren aurkeztuko ditugu materialen azterketek azaldu dituzten fenomeno esanguratsuak ilustratzeko adibideak. Lau ikasleren ibilbideetatik hartuak dira. Ikus ondoren corpusaren zehaztasunak: 
Itziar Iriondo, Itziar Plazaola, Teresa Zulaika

\begin{tabular}{|c|c|c|}
\hline $\begin{array}{c}\mathbf{2 0 1 3 / 2 0 1 4} \text { ikasturtea } \\
\text { 4. maila }\end{array}$ & $\begin{array}{c}\text { Euskara } \\
\text { aztertua / guztira }\end{array}$ & $\begin{array}{c}\text { Ingelesa } \\
\text { aztertua/guztira }\end{array}$ \\
\hline $\begin{array}{c}\text { Hasiberriek grabatutako } \\
\text { eskola-saioak }\end{array}$ & $9 / 9$ & $10 / 15$ \\
\hline $\begin{array}{c}\text { Autobehaketak } \\
\text { Saio bakoitzaren batez } \\
\text { besteko iraupena: } 60\end{array}$ & $8 / 8$ & $10 / 10$ \\
\hline $\begin{array}{c}\text { Talde behaketak } \\
\text { Saio bakoitzaren batez } \\
\text { besteko iraupena: } 60\end{array}$ & $0 / 0$ & $3 / 3$ \\
\hline $\begin{array}{c}\text { GRALak } \\
\text { Batez besteko } \\
\text { orrialde-kopurua: } 25\end{array}$ & $8 / 8$ & $10 / 10$ \\
\hline $\begin{array}{l}\text { Corpuseko beste } \\
\text { materialak }\end{array}$ & $\begin{aligned} \text { - Mintegietako gidoia } \\
\text { - «Sarrera moduluare } \\
\text { tako bideoak: } 2 \text {. } \\
\text { - Foroetako gaiak eta } \\
\text { - Hasiberrien egunero } \\
\text { - Ikastetxeetako bisite } \\
\text { - PIIIko txostenak: } 18 \\
\text { - Transkripzioak: ikas } \\
\text { behaketetakoak: } 80 \text { ' } \\
\text { - GRALen posterrak: }\end{aligned}$ & $\begin{array}{l}\text { latutako lehen mintegie- } \\
8 . \\
\text { orrialde-kopurua: } 15) \text {. } \\
\text { saioetakoak: } 60 \text { '; auto- }\end{array}$ \\
\hline $\begin{array}{c}\mathbf{2 0 1 4 / 2 0 1 5} \text { ikasturtea } \\
\text { 4. maila } \\
\end{array}$ & $\begin{array}{c}\text { Euskara } \\
\text { aztertua / guztira }\end{array}$ & $\begin{array}{c}\text { Ingelesa } \\
\text { aztertua/guztira } \\
\end{array}$ \\
\hline $\begin{array}{c}\text { Hasiberriek grabatutako } \\
\text { eskola-saioak }\end{array}$ & $3 / 4$ & $10 / 22$ \\
\hline $\begin{array}{c}\text { Autobehaketak } \\
\text { Saio bakoitzaren batez } \\
\text { besteko iraupena: } 60\end{array}$ & $3 / 3$ & $10 / 10$ \\
\hline $\begin{array}{c}\text { Talde behaketak } \\
\text { Saio bakoitzaren batez } \\
\text { besteko iraupena: } 60\end{array}$ & $0 / 0$ & $4 / 4$ \\
\hline $\begin{array}{c}\text { GRALak } \\
\text { Batez besteko } \\
\text { orrialde-kopurua: } 25\end{array}$ & $3 / 3$ & $10 / 10$ \\
\hline $\begin{array}{l}\text { Corpuseko beste } \\
\text { materialak }\end{array}$ & $\begin{array}{l}\text { - Mintegietako gidoia } \\
\text { - Foroetako gaiak eta } \\
\text { - Hasiberrien egunero } \\
\text { - Ikastetxeetako bisite } \\
\text { - PIIlko txostenak: } 13 \\
\text { - Transkripzioak: ikas } \\
\text { behaketetakoak: } 60 \text { ' } \\
\text { - GRALen posterrak: }\end{array}$ & $\begin{array}{l}3 . \\
\text { orrialde-kopurua: 15). } \\
\text { saioetakoak: } 20 \text { '; auto- }\end{array}$ \\
\hline
\end{tabular}




\subsection{Azterketa tresnak: ekintza enuntziatuak}

Corpusean bildutako testuak «Jarduera aztertzeko galbahea» (ik. galbahe osoa, eranskin 1ean) tresnaren bidez aztertu dira. Azterketek ekintza enuntziatuak dituzte fokuan, egileek jardueraren alderdi oro deskribatzeko erabiltzen dituztenak, hain zuzen ere. Ikasleak eta ikertzaileak, irakaskuntza jardueraz aritzerakoan, bigarren mailako tipifikazioan dihardute, jarduera unearen ondorengoan. Azterketak berbaldi horietako ekintza enuntziatuei erreparatuko die. Irizpide horien artean badira edukiari lotuak daudenak, ekintza islatzen duen sintaxiari eta enuntziazioari berari dagozkionak; modalizazioak, batik bat. Halakoek gauzatzen baitute enuntziatzaileak jardueraz duen posizioa, zehaztuz ahalmena (Ikasleentzat gai bat interesgarri bihurtu dezakegu nahiz eta ez izanik. 6.3.2. atala), nahia (Hasiera batetik partaidetza orekatua nahi nuen, denon aldetik berdina izatea, ik. 6.3.2. atala), balorazioa (Nire helburuak bete nituen! Hobetu zitezkeen detaileak baziren arren, ikasleak, eskatu niena egiteko gai izan ziren. ik. 6.2.1. atala), eta abar. Halako diskurtso-aztarnak bai ikaslearengan bai ikertzailearen adierazpenetan aztertzen dira.

\section{AZTERKETAREN EMAITZAK ETA ONDORIOAK}

Aztertu ditugun lau kasuetan Practicumeko ikasleen artean komunak diren zenbait ezaugarri ageri dira. Lan honetan, arreta berezia eskaini diegu, beste hainbaten artean, hiru adierazleri: irakasle hasiberriaren rolei; jarduerarekiko arretaren bilakaerari eta hizkuntzaren didaktikako zenbait alderdiren aipamenari.

Hiru adierazleak honako arrazoi hauengatik aukeratu dira:

1. Maiz ageri dira ikasleen diskurtsoen azterketetan.

2. Irakaskuntza-prestakuntzarako eduki berriak azalarazten dituzte.

3. Esanguratsuak dira hizkuntzaren didaktikaren esparruan.

\subsection{Hasiberrien baldintza ezohikoak}

Hau dugu alderdi komun adierazgarrienetako bat PIIIko esperientziari buruz bildu dugun corpusaren azterketetan: irakasle hasiberri bilakatzen dira hiru hilabetez, eta, egoera horretan, ezohikoak diren baldintzetan jardun behar izaten dute; inoiz lehenago eta, ziurrenik, ondoren ere biziko ez dituzten baldintzetan aritzen dira. Aste horietan ez dira ez ikasle eta ez irakasle. 


\subsubsection{Ikastetxeko tutorearekiko harremana}

Unibertsitateko ikasleek praktikaldian betetzen duten hasiberriaren rola ezberdina izan daiteke egoeraren arabera, ikastetxean egokitu zaien tutorearekiko harremanak eraginda: kasu batzuetan, maiz beteko dute benetako irakaslearen lana eta haiek prestatu eta kudeatuko dituzte saioak; beste batzuetan, aldiz, oso gutxitan izango dute esku-hartze hori. Ikastetxeetako tutoreen aldetik laguntza-harremana izaten da gehienetan unibertsitateko ikasleek jasotzen dutena, baina tutore guztiek ez dute modu berean interpretatzen Practicumeko ikaslearen zeregina eta, batzuetan, ez da bereizten etorritako ikaslea PI, PII edota PIIIkoa den. Zenbaitetan, gutxietsiak ere sentitu daitezke PIIIko ikasleak. Egoera horrek eragin handia izan dezake beraien jardueran.

Corpusean maiz azaltzen dira ikastetxeko tutorearen eta hasiberriaren arteko harremanei erreferentzia egiten dieten pasarteak. Jardueraren eskuhartzeaz aritzen direnean, gelako ikasleak diskurtsoaren bigarren planoan agertzen dira. Azterketak azaltzen du ikastetxeko tutorearen eta hasiberriaren arteko agentibitatearen partekatzea dela hizpide (galbaheko 3. jardueraren bilakaeraren deskribapena); horrelakoetan jardueraren «parte-hartzea» da fokuan dagoena, eta horrek sorrarazten dituen eduki mental eta emozioak (ik. galbahean 3.3).

Mireia izeneko ikasleak, adibide hauetan ikus daitekeenez, esperientzia ezberdinak izan ditu Practicumean. Irakasle papera oso-osoan bete ahal izatea pozgarria eta garapenerako lagungarri izan zaio. Jardueran bertan rola bete-betean egiteko konfiantza ematea eskatzen du hasiberriak, beharrezkoa da prestakuntza hitzarmenean oinarrituz jardutea. Gomendioak, aholkuak beste momentu batean, jardueraz kanpo egitearen pertinentzia azaltzen da hemen.

\section{Mireia. 2013-2014. Atzerriko Hizkuntza. PIIIko txostena}

(5. or.) My participation and feedback with all the teachers was not the same; it was very easy to take part with some of them, but not with others. So, I decided to take advantage of the circumstances and to choose the most suitable and productive for me.

(Ikastetxeko nire tutore guztiekiko parte-hartze eta feedbacka ez zen bera; batzuekin parte-hartzea oso erraza zen baina besteekin ez. Beraz, egoera hori baliatzea eta niretzako egoki eta emankorrena zena aukeratzea erabaki nuen.) 
Mireia. 2013-2014. Atzerriko Hizkuntza. Autobehaketa

(7:35) M: Bueno, eta gero superurduri jartzen nitzan irakasleak hitz egiten zuenian, eta, ez dakit, sentitzen nitzan pixkat, jo..., ez dakit ulertuko didazun, baina, ez banitz ondo egiten ari bezela...

Ikertzailea: Autoridadea kentzen zizula?

M: baita ere, bai, baino... orduan ni, egiten zun eh... zalantza sortu bezela, jo, ez naiz ari ondo iten edo ez naiz ari ondo azaltzen edo.... eta, egia esan, klaro, nahiko konplikatua da irakasle bati hori esatia, ba, mesedez, utzidazu neri baino, bai, aitortu behar det neretzat eragozpen bat zala.

(12:58): M: Beste gelan [...] beste irakasle batekin, partehartzia oso desberdina izan da, egia esan [...] eh, bueno ba, ez deu egin hasiera batian hitzeiten genun guztiya, klaseak prestatu, gero berekin konparatu... hori ez, ez zen egin hori, baina bai, ez dakit, konfiantza haundiya eman ditela, esateizut, klasiak eman ditutela nik bakarrik, nik prestatuta, gero pasatzen genun, gero ikusikoitugu guk ere bai, gida jarraituz beti ez? [...] baina neretzat izan da esperientzi bat... o sea, utzi diala... asko disfrutatu det eta baita material pila bat nik prestatu det.

Pasarte hauetan Gurutzek aipatzen du eskolak ematean, tutorearen baldintzapean egon dela, eta egoera hori orokorra dela, «gu» bidez egiten baitu adierazpena. Gainera, haren ustez, baldintza horiek era arbitrarioan alda daitezke.

\section{Gurutze. 2013-2014. Euskara, Hezkuntzarako Tresna. Autobehaketa}

(41:22): G: Momentu hortan haserre jarri nitzan [...] igual ez zan nik espero nuna ez? [...] berak (tutoreak) esan zidan hasiera batean utziko zidala malgutasun gehiago ez? ba nik emateko nere klasea nahi nuen bezela, nik prestatzeko [...] ordun, bera altxatzen da, hasten zait esaten "ardurak, ardurak» (saioa amaitzeko egin ohi dituzten adostutako ariketak) hola keinuka bezela eta ordun hasarre jarri nitzan.

(1:08): G: Nik, adibidez, ez det parte-hartze asko asko izan, esan nahi det, klaseak ematerako garaian... bueno, hori ere da irakaslearen baldintzapean, baino, askotan, beldurra dugu irakasleari esateko...

Hasiberriek Practicumean zehar ematen dituzten saioetan jokatu behar duten paperaren inguruko kezka nabari da zenbait kasutan. Gogoeta ugari 
egiten dute horren inguruan. Zenbaitetan, tutorearekin irakasle-rola partekatzeak egoera deserosoetara bultzatzen ditu.

Beste zenbaitetan, berriz, poz handia eta prestakuntza prozesuan bultzada eta laguntza paregabe gisa hartzen dute honako adibide hauetan ikus dezakegunez.

Maddi. 2013-2014. Atzerriko Hizkuntza. GRAL.

(6. or.) Something related to what students were doing in that moment in class could be done or something absolutely different, due to the fact that the tutor gave me all freedom to do what I considered. The decision was to do something in relation with what they were working on because it was interesting and furthermore, it was not a good idea to start with something new just for a day.

(Tutoreak nahi nuena egiteko aukera eman zidan, egiten ari zirenaren hariari jarraitzea edo guztiz bestelakoa zen zerbait egitea. Egiten ari zirenarekin jarraitzea erabaki nuen, interesgarria zelako eta, gainera, ez zitzaidan ideia ona iruditu egun bakarrerako zerbait ezberdina egiten hastea.)

(14. or.) My school tutor's advice in order to improve the activities were really helpful, taking into account the difficulties that some children could have.

(Nire tutorearen aholkuak oso lagungarriak izan ziren jarduerak hobetzeko zenbait ikaslek zuen zailtasunak zirela-eta.)

Maitane. 2014-2015. Atzerriko Hizkuntza. Talde-behaketa

(59:39) Irakasleak esan zidan asko gustatu zitzaiola eta berak jarraituko zuela horrelako gauzak egiten eta horrek poz handia ematen $d u$...

Practicumaren alderdi honek ikertzaileon arreta merezi du elkarlanean gutxieneko adostasuna lortzeko.

Badira, nazioartean irakasle rola bi lankideren artean egitearen onurabaldintzak aztertzen dituzten lanak (Lussi Borer \& Muller, 2016). Problematika hori adituaren eta hasiberriaren arteko rolen banaketara zabaltzea aberatsa litzateke prestakuntzarako. 


\subsubsection{Egoera ezezaguna}

Bestalde, ikastetxeko ikasleek ere hainbatetan ez dute argi izaten zein den hasiberrien egitekoa eta egoera horrek bultzatzen ditu benetako irakaslearena ez den papera antzeztera. Jasotako corpusean aztarna ugari aurki dezakegu gai horren inguruan. Jarduera aztertzean (galbahean 1. puntuan) egileen estatusa auzitan jartzen da, ikastetxeko tipikalitatetik ez datorrelako, edota, gelako ikasleek hasiberria ez dutelako onartzen egile paperean. Agentibitate muina (galbahea 3.2) ez dago sendotuta.

Horren adierazle, adibide bat aurkezten dugu:

Maitane hasiberriak adierazten du egoera ezohikoa zela; alde batetik, irakaslea bera zelako eta ez ohiko tutorea eta, bestetik, berak proposatutako jarduera ikasleentzat berria zelako. Hala ere, ez zuen haurrek egun horretakoa zerbait ezohikoa balitz bezala bizitzerik nahi, nahiz eta saioan zehar bere jarduera berezitzat aurkeztu.

Maitane. 2014-2015. Atzerriko Hizkuntza. Saioaren grabaketa

(2:23) M: «As I told you, today we are going to do something different yes? You are going to become chefs...»

(Esan bezala, gaur, ezberdina den zerbait egingo dugu, bai? Sukaldari bihurtuko zarete...)

Maitane. 2014-2015. Atzerriko Hizkuntza. Autobehaketa

(8:48) M: «Hau da gaur bakarrik egingo deguna, ez pentsa ez dakit zer» (bere burua eszenifikatuz) [...] hori ez zan nere helburua eta hola ere, igual ni... nere papera beraiek ere ez dute hain garbi ikusten, porque ikusten baldin bazuten liburuak hartu eta ez dakit zer... ba igual ikusiko zuten bestea (tutorea) bezela, baina kasu hortan igual ez zidaten berdin ikusiko

Ikastetxeko ikasleen rola eta bere rolaren arteko lotura azaltzen du, jardueran agentibitate plurala garbi du: «nere papera beraiek ere ez dute garbi ikusten», eta egoera ikasleentzat ezohikoa izateak eginkizuna zailtzen dio. Jarduera ezaugarritzeko agentibitate muina (ik. galbahean 3.1., Eranskina 1) izenorde sistema honen bidez marrazten du:

ni; nere - gu (ikasleak-ni) - berak; haiek (ikasleak) - bestea (ikastetxeko tutorea). 
«Bestea» izendapen bitxiak ikastetxeko tutorearen eta bere buruaren artean berdintasun-ezberdintasun tentsioa agertzen du: «ni eta bestea» alegia, beste irakaslea, ni bezala irakasle rolean egon ohi dena, antzekotasuna, parekidetasuna adierazten du. Aldi berean badirudi tutorearen jarduera bezalakoa ez duela egin nahi, ez duela egin behar ala ezingo duela egin. Azpimarratzekoa da, bestetik, nola osatzen duten hasiberriaren diskurtsoa saioan diharduten «gu» horretan, berak (hasiberriak) eta ikasleek; tutorea («bestea») jardueratik kanporatzen du. Ohiko irakaslearen jarduera «liburuak hartu eta...» moduan irudikatzen du.

\subsubsection{Irakaskuntzari buruzko jarrerak}

PIIIko ikaslea irakasle hasiberria da baina baditu ezagutzak eta irizpideak irakaskuntzaz. Ikastetxeko tutorearen lan-motarekin topo egiten duenean, zenbaitetan ez da ados egoten ikusten duenarekin (ez zait gustatzen, ez nago ados...). Hasiberriak hezkuntzaz dituen teoriak, iritziak ez dira bat etortzen ikastetxean egiten denarekin, erabilitako metodologia edo ohiturekin. Halakoak maiz ikus daitezke corpuseko iritzi kritikoetan. Galbaheko 3.5. Irakaslearen intentzio eta motibazioak eta 4. Eginikoaren balorazioa izeneko itemei esker jasotzen dira hasiberriak jardueraz dituen irizpideak eta egiten dituen balorazioak. Zenbaitetan hasiberriak berak aukeratutako jarduera tipoa eta ikastetxeko tutorearena alderatzen dira.

Saioen hasieran egunero egiten diren errutina izeneko jarduera tipikoez ari da hasiberria adibide honetan:

\section{Maitane. 2014-2015. Atzerriko Hizkuntza. Autobehaketa}

(3:40): M: Eta neri pertsonalki ez zait gustatzen hola egitia; eta gainera ikusten nun, bati, bueno, ba nahiko ondo moldatzen bada, bestiak entzuten die, baina ataskatzen baldin bada eta zea, bestiak ya, automatikamente, deskonektatu egiten due, eta, ordun, iruitzen zait alperrik ari diala, baña, ez dakit, baita ere beste andereñuak egiten zun eta ordun in nahi izan nun. Gaizki! baña...

Maitanek bere iritzia pertsonaltzat hartzen badu ere, jardueraren azterketan oinarritzen du kritika, alegia, ikasleen jarreren behaketan.

Hurrengoan, gelako ikasleen autonomia du mintzagai. Haurrek jarduerak osorik beren kasa egitea edo, lana erraztearren, laguntza gisa, ariketak nolabait «erdi-eginak» ematea alderatzen ditu; azken hauetan atazaren erronka didaktikoa galtzearen arriskuaz jabetzen dela dirudi. 
Maitane. 2014-2015. Atzerriko Hizkuntza. Autobehaketa

(34:06): M: (barrez) baiña... (tutoreak) esan zin igual hobeto zala hola ematia beraiei (fotokopia bat) eta hola ariketan ikusten zituzten izenak eta ya esta. Nik, berez, nahiago nun beraiek lana egitia, dekoratzia, ez dakit zer, kartel polit bat egitia danon artian zerotik hasita [...] iruitzen zitzaidan motibagarriago eta pertsonalago, ez dakit, hola eman beharrian eta izenak idatzi bakarrikan... baina berak, adibidez, bazekan ohitura hori, iya erdiya baino gehiago eginda ematia, beti, baina bai hauekin, bai 5. mailakin eta bai 2. mailakuekin. Nik igual geyo utziko niyoen beaien... beaien kasaka antolatzeko edo.... ez dakit esplikatzen naizen... [...] nahiz eta denbora geyo pasa, gai izango ziala idazteko... baina hori askotan, eta askotan esplikau niyon baina... (parrez)

Eskolako metodologiaren inguruko kritikak ere azaltzen dira, hala nola, gauzak beste era batera egin nahia, espazioaren antolaketa aldatzea, elkarreragina...

Mireia. 2013-2014. Atzerriko Hizkuntza. Autobehaketa

(13:58): M: Gauza batzukin ez negon, ez neon bate konforme.

Ikertzailea: Eta ordun honekin saiatu zera hausten edo konplementatzen, osatzen piskat hori ez?

M: Bai, eta igual gehiegi liatu naiz baino bueno, azken batian, nahi izan nun...

Maddi.2013-2014. Atzerriko Hizkuntza. Autobehaketa

(3:19): M: Normalian ez dia egoten hola eserita, normalian egoten dia binaka, bueno, azken hontan egoten dira hola (eskuekin) lerron, bosnaka o seinaka, hola, lau lerro, baina grabazioan aurretikan ya erabaki nun jartzea hola, U modun, ze bestela jokua itteakoan ez zuten eukiko lekuik. Hola, lekua eukiko zuen elkarri galderak egiteko, hitz egiteko eta muitzeko komodoago.

(33:41): M: Igual in behar zuen banaka idatzi, baino ez dakit, eske nola ez zuen egin eztaere beine, nahi nun elkarri laguntzea baina kasu hontan ez zian ari elkarri laguntzen. 
Itziar Iriondo, Itziar Plazaola, Teresa Zulaika

Gurutze. 2013-2014. Euskara, Hezkuntzarako Tresna. Autobehaketa

(4:23): G: Irakasleak (tutoreaz) ez ditu gai hauek, elkarrizketa hauek eh... inoiz jarraitu. Lantzen dira elkarrizketak, o sea, irakasleak ba haurrekin elkarrizketa lantzeko batzutan gai batzuk jorratzen ditu, baino ez dira... erlazio hau, hartuemana irakaslea eta ikaslearen artean ez da ematen.

Gurutze. 2013-2014. Euskara, Hezkuntzarako Tresna. GRAL.

(12. or.) «Nire ustez irakaskuntza oso zuzendua dago gaur egun, gela horretan ere horrela gertatzen da eta beraz ez nago ados prozedura horrekin; horregatik, saiatu nintzen saio irekiagoa egiten,jarraibide batzuk markatuz baina haurrei modu librean espresatzeko aukera emanez».

Adibide hauetan azaltzen da maiz hasiberriak irakaskuntzari buruz dituen iritziak kontraesanean erortzen direla gelako ohitura eta metodoekin: gelako elkarreraginaren kontzepzioa, ikaslearen autonomia, atazaren erronka didaktikoa gordetzea. Hasiberrien ezagutza profesionalen adierazgarri gisa har daitezkeela dirudi nahiz eta zenbaitetan tutorearen iritzi eta esperientziarekin talka egiten duten (ik. baita ere 6.1.3.).

Hauetako hainbat adierazpenetan, hasiberrien prestakuntzan gogoetaren garapena nabari daiteke, alegia, Practicum garaian behatutakoa aurreko ezagutzekin alderatzen dute eta ondorioak ateratzen dituzte. Adibide honetan ikus dezakegunez, Gurutzek deskribatzen duen egoeran, tutorearen jokabidea, ikasleei ezezik, hasiberriari ere zuzendutakotzat har daiteke.

Gurutze. 2013-2014. Euskara, Hezkuntzarako Tresna. PIIIko txostena

(8. or.): «Irakasle ona dela iruditzen zait, bere izaerak asko laguntzen du, pertsona alaia da eta gauza pertsonalak lan mundutik at uzten ditu. Haurren kezkei, beldurrei, beharrei modu egokian erantzuten saiatzen den arren, zenbait egoeretan beste bide batzuk erabiltzeko beharra ikusi dut. Ikasleak bizi diren etapa honetan, inozentzia oraindik ere presente da haien barruan. Modu honetan irakasleak ironia asko erabili du ikasleekin eta hauek ez dira gai izan irakasleak erabiltzen duen hori ulertzeko.

$$
\text { (...) }
$$

Bestalde, autonomia bultzatzea ezinbestekotzat ikusten du, baina hori lantzeko erabiltzen duen bidea ez dut partekatzen. Ikasleak autonomiaz lan egin dezaten eta euren autonomia izan dezaten bultzatzen dut nik ere, baina hori bideratzeko modu ezberdinak daude.» 
Azken finean, PIIIko ikaslearen rolak dituen mugez ohartzen dira, eta, honako adibide honetan ere azaltzen denez, urratsen bat emateko aukera bai baina hezkuntzari buruz duten ikuspegia guztiz garatzeko dituzten mugez jabetzen dira.

Maitane. 2014-2015. Atzerriko Hizkuntza. GRAL.

(14. or.) The methodology of the school cannot be changed from one day to another. The teacher needs to adapt to the school habits and methodology, but some changes can be done to teach a class.

(Eskolako metodologia ezin da aldatu egun batetik bestera. Irakasleak eskolara egokitu behar ditu ohiturak, metodologiak..., baina zenbait aldaketa egin daitezke eskola ematerakoan.)

Gatazka une hauek konpontzea beti posible ez bada ere, unibertsitateko irakasleen eta ikastetxeko tutoreen arteko elkarlanaren beharra ikusarazten dute, prestakuntza hitzarmena beren artean zehaztearen premia.

\subsubsection{Jardueraren ezagutza mugatua}

Protokolo zehatzik ez dagoenez PIIIko ikaslea arituko den ikasgelako ikasle taldeari buruzko informazioa hasieran eta era egokian jasotzeko, ikastetxeko tutorearen esku egoten da modu batean edo bestean egitea. Oinarrizko informazio hori helarazteko eraren arabera ere, hasiberriek ez dituzte ezagutzen, hainbatetan, ikasgelaren nondik-norakoaren benetako baliabide eta bitartekoak. Ikastetxeko tutoreak jarduera bat proposatzen duenean informazio ugari du, egoeraren berri, ikastetxeko ikasleen gaitasun, disposizio eta abarren inguruan; badaki ikasleak non dauden, zer nolako maila duten... eta hasiberriari horretan gabeziak nabaritzen zaizkio. Egoera horrek, izaera berezia erantsiko dio irakasle hasiberriaren jarduerari.

Ikasleek arretarik ez jartzearen inguruan:

Maitane. 2014-2015. Atzerriko Hizkuntza. Autobehaketa

(13:24): M: Adibidez hori nahiko frustrantia egiten zitzaidan [...] ez dakit ingelesa delako, edo ni naizelako [...].

(21:35): M: Nei iruitzen zait desmadratzen ziala inglesian, bat, ez zitzaielako gustatzen... baina (tutoreak) ateratzen zun karakterra [...] ez, nik uste, aspertu iten ziala ta ez zitzaiela gustatzen. 
Jarduera proposatu eta izandako erantzun gabeziaz:

Mireia. 2013-2014. Atzerriko Hizkuntza.Autobehaketa

(37:04): M: Ez nekin, ez nekin, eo lotsatuta zeuden jolastian...

Ikertzailea: Baino nahiko ohituta daude hortara ez? edo ez?

( sorbaldak altxatzen ditu ez dakiela adieraziz)

M: Erantzuna izan zan...

Ikertzailea: Espero ez zenuena.

Aurreko transkribapenetan ikusten da, adibidez, irakasle hasiberriek ikasleak ondo ezagutzen ez dituztenez, ez dakitela zehazki zer den gertatzen zaiena, informazio faltagatik ez direla arazoa ongi interpretatzeko gai sentitzen.

Adibide hauetan ikus dezakegunez, irakasle-tutoreen laguntza behar izaten dute zenbait klabe interpretatu eta ulertzeko, eta, ondoren, gero eta autonomia handiagoz, beren kabuz, irakaskuntzari, eta, zehatzago, kasu hauetan, hizkuntzaren irakaskuntzari buruzko hainbat ondorio atera ahal izateko.

Maitane. 2014-2015. Atzerriko Hizkuntza. Egunerokoa

(15. or.) Sometimes we think that we have the perfect activity that it will work, but actually it is not. Maybe it is not so attractive for students or it is not so appropriate to achieve our aims. Our teachers helped us a lot in that aspect and we have to ask them.

(Batzuetan, funtzionatuko duen jarduera perfektua dugula uste dugu, baina ez da hala. Beharbada, ez da ikasleentzat hain erakargarria, edo ez da gure helburuak lortzeko egokia. Gure irakasleek horrelakoetan laguntza handia eman izan digute eta haiei galdetu beharko genieke.)

(15. or.) We don't have to underestimate children skills and we have to try to bombard them with all the information we can. It doesn't matter if they don't understand all, the most important thing is to reach the aims we want.

(Ez ditugu haurren trebeziak gutxietsi behar eta saiatu behar dugu ahalik eta informazio gehien ematen. Guztia ulertzen ez badute ere, berdin da, garrantzitsuena gure helburuak betetzea da.) 
Maitane. 2014-2015. Atzerriko Hizkuntza. PIII txostena

(1. or.): I realized that English classes were a bit boring for the students and I started to think what was not going properly. Nevertheless, not everything was such badly done, I have also learnt a lot of strategies and tools which I think will be useful in the future to teach the language.

(Ikasleentzat ingeles saioak aspergarriak zirela konturatu nintzen eta arrazoiaz pentsatzen jarri nintzen. Hala ere, dena ez zen hain txarra. Etorkizunerako hizkuntza irakasteko erabilgarriak izango zaizkidan estrategia eta tresna ugari ikasi nituen.)

Adibide honetan, irakasle hasiberriaren rolak dakarrena laburtzen saiatu da Mireia, hainbat alderdi kontuan izan behar baita.

Mireia. 2013-2014. Atzerriko Hizkuntza. GRAL.

(10. or.) Being novel teachers presents many doubts and insecurities, but also a great wish to experiment and test personal ways of doing according to all academic resources acquired, and to the context that real classrooms propose. This challenge gets even more complex when we expect to teach both meaningful communication about particular and motivating content for students, and intentional language teaching.

(Irakasle hasiberriak izateak hainbat zalantza eta segurtasunik eza dakar, baina baita esperimentaziorako eta ikasitako baliabideak ikasgelako testuinguruak eskaintzen duen erronka praktikan jartzeko gogoa ere. Hori zailagoa bihurtzen da ikasleentzat esanguratsuak diren edukiak era komunikatibo eta motibagarrian irakatsi nahi ditugunean...)

(20. or.) Without doubt teaching is a very complex process, specially for novel teachers. Classrooms mean an uncertain challenge that beginners have to face with all their academic background and knowledge, but also with as much intuition, versatility, common sense and flexibility as possible. Every school, every classroom and every student has its own particular needs, and this is an essential feature that should be taken into account.

(Zalantzarik gabe, irakastea prozesu konplexua da, bereziki irakasle hasiberrientzat. Ikasgelak, hasiberriek beren ezaguera akademikoen laguntzaz aurre egin beharreko erronka ezezagunen guneak dira, baina baita ahalik eta intuizio, moldaerraztasun, zentzu eta malgutasun gehienez. Ikastetxe, ikasgela eta ikasle bakoitzak berezko beharrak ditu, eta hori da kontuan izan beharko litzatekeen ezinbesteko alderdia.) 


\subsection{Norbera epaitzetik jarduera aztertzera}

Haur Hezkuntzako eta Lehen Hezkuntzako ikasleekin burututako prestakuntza-prozesuan zehar, nabarmena da beren begiradaren bilakaera. Aztertutako corpus zatietan maiz ikusi ahal izan da hori. Hasieran, askok pentsatzen dute haiek epaitu behar ditugula: haien gorputz-adierazpena, hizkuntza-maila, eta abar. Gero, norberaren ezaugarri pertsonaletatik, irakasle-izatearen ezaugarrietara ematen dute pausoa; ondoren, beren ikasleengana eta, azkenean, jardueretara. Ibilaldi horretan, gure ustez, krisialdia gertatzen da, rol aldaketa eta heldutasunerako pausoa.

Azterketa-inguramenduaren muina ulertzen dutenean, hasiberriek ez dute hainbeste esaten nola egin duten lana (ondo, gaizki, urduri nengoen...), baizik eta nola garatu den jarduera, aproposa zen ala ez, lanak zentzua ote duen hizkuntzen irakaskuntzarako, eta abar. Egozentrismo kutsuko lehen begirada batetik (adibideak: ahoskera, hitz azkartasuna, gorputza...), ezaugarri pertsonalak alde batera uztera pasatzen dira eta zenbaitetan, poztasuna ageri da. Lasaitu ondoren hasten dira fokua aldatzen, arreta-gunearen desplazamendua gertatzen da; jardueraren konplexutasunaren ardura hartzen dute, irakasle rolerako bira, eta, ondorioz, ikastetxeko ikasleen disposizioak (adibideak: ez dute kasurik egiten...), ataza, iraupena, eta abar hartzen dituzte mintzagai zorroztasun handiagoz.

Garapen hori baliagarria da jarduera berrietarako, badakite zeri erreparatu behar dioten aurrerantzean.

Ikertzaileon rol nagusia ezinbestekoa da, saioa egina dutela jakinarazi behar zaie, eta hurrengo urratsa emateko garaia dela.

Adibide hauetan ikus daitekeenez, hasiberriak arreta bere buruari eskaintzen dio autobehaketaren lehen minutuetan, bere kezka da irudietan nola agertzen den. Analisia aurrera joan ahala, hausnarketaren gunea jardueraren hainbat alderditara bideratzen da.

Lehen adibide honetan, irakasle hasiberriak autobehaketaren hasieran, ahoskera eta ahotsa ditu hizpide:

Mireia. 2013-2014. Atzerriko Hizkuntza. Autobehaketa

(4:32) M: Ahoskerarekin... bueno! oso harrituta, ze pentsatzen nun hobeto ahoskatzen nula, gero bideoan ikusten zea eta (aurpegi txarra jartzen du)

Ikertzailea: Eta ez zaizu gustatzen ahoskera?

M: Ez, eta ahotsa ere, klaro...

Elkarrizketa berean baina beranduago, taldekatzeaz dihardu, talde homogeneoak egin beharraz, beraz, jardueran jarri du fokua: 
(34:56) M: Izan zen eragozpen bat [...] gero oso desatsegina zen (taldeak homogeneoak ez izana) eta gero pila bat damutu nintzan.

Beste adibide honetan ere, hasieran, bere burua da iruzkin gehienen erdigunea:

Gurutze. 2013-2014. Euskara, Hezkuntzarako Tresna. Autobehaketa

(6:10): G: Nik ere, adibidez, hasi nintzan momentutik hizketan, hor eeee... esaldi bukaeran luzatzen deten «nukeeee» hori, orain ikusten detela, puf! ez zait bat ere gustatzen, egia esan, ez dakit, ez dakit zergatik eta ez dakit, hor igual burua, postura, hola jartzen detenean da nere burua babesteko, ez dakit, ikusp..., egoera bat, nik ustet or naola hasierako momentua... urduri, urduri sentitzen nitzan.

Horrelako azalpenak, gehienetan, behaketaren hasierako minutuetan ematen dira, eta ikertzailearen onespena bilatzen dute hasiberriek gorputz adierazpenaren eta begiradaren bidez ere. Ondoren, fokua jardueran edo ikasleengan jartzen hasten dira. Hasiberria ikasleen aldarteek eskatzen duten bere aldetikako jokabidea irudikatzeko gai dela ageri da adibide honetan, irakats jardueraren azterketa fina nabari da. Halakoetan, jantziago, askeago eta lasaiago nabari ditzakegu hasiberriak.

Ahozko adierazpena kudeatzea, jarduera tipikoaz:

(25:48): G: Gero ere konturatu naiz, adibidez, eeeh, denak hasten direnez beren bizitza kontatzen eta kontatzen, nik ez det mozten, adibidez, ez det esaten eskua altxa, behin bakarrik, uste det, hasieran daudenean, horrela, konturatzeko hitz egin behar dutela... [...] igual hor falta zaitena da moztea, bakoitzari hitza ematea, errespetatzea

Bestetik, prestakuntzan hasiberriek egiten duten ibilbidean beste bilakaera hau ere nabari da, oraingo honetan autobehaketetatik talde-behaketara pausoa ematean azaltzen dena. Hain zuzen, ibilbide hori egokia izaten da, bigarren momentuan taldean jardueraren azterketa egiten denean, fokua jardueran jarri ohi da eta. Berdinen arteko balioa handia da, ziklo horren barruan nagusia da taldearen garrantzia, parekideak duen bigarren berrespen-eginkizuna. Elkarrizketa profesionalak gauzatzen dira behaketa-taldean, irakasle jakitun bihurtzen dira parekideak, eta ezagutzak eremu profesionalean partekatzen dituzte. 
Itziar Iriondo, Itziar Plazaola, Teresa Zulaika

Mireia, Maddi eta Lurdesen arteko talde-behaketa. 2013-2014. Atzerriko Hizkuntza

(20:50): M: I don't know, now that I see the video again I think we worked on several skills and the class was well prepared, but I don't know...

(M: Ez dakit, orain bideoa berriro ikusita, iruditzen zait hizkuntza-trebetasun guztiak landu genituela eta saioa ongi prestatuta zegoela, baina ez dakit...)

(31:35): Mi: I found this kind of description, this part of the project, a bit out of any context because I don't see the point in learning to describe in a way that they are not going to use. It's not reality, it's not real to describe someone like this and I don't know, when I started to be critical about that methodology, it was something about that point.

(Mi: Niretzat, deskribapen mota hau, proiektuaren atal hau, edozein testuingurutatik kanpo ikusten dut nolabait, ez dut ikusten zertarako ikasi behar den inoiz erabiliko ez den era bateko deskribapenak egiten. Ez da errealitatea, ez da erreala inor horrela deskribatzea, eta, ez dakit, ni metodologia horrekin kritikoa izaten hasi nintzenean, horrelako zerbaitegatik izan zen.)

(33:20): M: So it's a step to start writing descriptions and once they know how to describe this kind of faces they know how to describe a normal face. It's true that we can start with the normal face and then with the special ones... I think it was funny, but that's my point and I think they liked creating their faces, maybe changing the shapes, maybe having two triangles for the eyes and I don't know...

(M: Beraz, urrats bat da deskribapenak idazten hastea eta, aurpegi mota hau deskribatzen badakitenean, jakingo dute nola deskribatu aurpegi normal bat. Egia da aurpegi normalarekin hasi gaitezkeela eta gero bereziekin... nik, dibertigarria zela pentsatu nuen, baina hori nire iritzia da eta uste dut gustatu egiten zitzaiela beren aurpegiak sortzea. Beharbada formak aldatuz, bi triangelu begietarako jarriz, eta, ez dakit...)

\subsubsection{Azterketa prozesuaren eragina}

Autobehaketa eta talde-behaketen ondoren, Practicum txostenean eta GRALean, garatutako prozesuaz hausnarketa egiten dutenean, argi aurki ditzakegu begiradaren garapen horien aztarnak. Hasiberriak hainbatetan bere prestakuntzari buruzko gogoeta sakona egiten du eta behaketa eta azterketa prozesuaren onurak azpimarratzen ditu. 
Maitane. 2014-2015. Atzerriko Hizkuntza. GRAL.

(3. or.) While I was watching the video and making comments about it, I was being recorded at the same time. We could say that the most important content is the comments I make and the conclusions I get from the class recording. From those comments I could get several issues to be investigated or I could see which my worries were. I could discover lots of things that I didn't realize while I was teaching the class. I felt satisfied with the class I gave and I also felt alleviated after watching the recording as things went better than I thought. I could get possible hypothesis to work on with and do research about them.

(Bideoa ikusi eta komentarioak egiten ari nintzenean, bideoz grabatu ninduten. Nik esaten nuena zen garrantzitsuena, eta grabatutako saioaz ateratako ondorioak. Komentario horietatik ikertu zitezkeen kontuak atera ziren. Nire kezkak plazaratu ziren. Eskola ematen ari nintzela oharkabean joan ziren hainbat alderdi agerian geratu ziren. Eman nuen klasearekin pozik geratu nintzen, lasaitua hartu nuen pentsatzen nuena baino hobea izan zelako. Zenbait hipotesi atera nituen ondoren ikertu eta lan egin ahal izateko.)

Maddi. 2013-2014. Atzerriko Hizkuntza. PIII txostena

(10. or.) It is true that I was obsessed with the mistakes I had with the material and with the lack of silence in the lesson I couldn't see things that worked well. After watching the video I realized that the students were able to ask and answers the questions, gather in groups, write the description of their desk genie and then, describe it aloud. I achieved my aims! Although there were some details to improve, the students were able to do what I asked them and apart from that, they were really motivated and happy doing the activities, so taking into account all these conclusions I think that the positive things tipped the scales.

(Egia da hasieran obsesionatu nengoela materialarekin izan nuen akatsa zela-eta, saioan zehar isiltasunik lortu ez nuelako, eta ezin nuen ongi atera zena ikusi. Bideoa ikusi ondoren konturatu nintzen ikasleek galderak egin eta erantzun ahal izan zituztela, taldeka lan egin zutela,jeinuaren deskribapenak idatzi zituztela eta ondoren ikaskideen aurrean aurkeztu. Nire helburuak bete nituen! Hobetu zitezkeen detaileak baziren arren, ikasleak, eskatu niena egiteko gai izan ziren, eta, horrez gain, motibatuta eta pozik ari ziren jardueretan, beraz, ondorio horiek guztiak kontuan izanda, alderdi onek besteak gainditu zituzten.) 
Itziar Iriondo, Itziar Plazaola, Teresa Zulaika

Mireia. 2013-2014. Atzerriko Hizkuntza. PIII txostena

(11. or.) While watching the video I felt guilty for all the things I did wrong. I was almost looking for my mistakes...

(Bideoa ikusterakoan, gaizki atera zitzaizkidan gauza guztietan jarri nuen arreta. Akatsetan jarri nuen arreta, horien bila nenbilen...)

(11. or.) The self confrontation was very significant; I started to change opinions about what had happened through the lesson. Things that I found very worrying in that moment started to lose importance, and my attention was directed to some other aspects of the lesson which I didn't notice before. I think sometimes we may get stuck for an insignificant reason, and surprisingly not be aware of other important matters that are happening at the same time.

(Autobehaketa oso garrantzitsua izan zen, saioan gertatutakoari buruzko nire iritzia aldatzen hasi nintzen. Oso larritzat hartzen nituen gauzak garrantzia galtzen hasi ziren eta nire arreta saioaren beste alderdietara zuzendu nuen, lehen oharkabean joan zirenetara. Zenbaitetan, txikikerietan zentratzen gara, eta, harrigarria den arren, aldi berean gertatzen ari diren beste hainbat alde garrantzitsu alde batera uzten dugu.)

Mireia. 2013-2014. Atzerriko Hizkuntza. PIII txostena

(15. or.) I am really happy about my experience in this practicum at school. But also about this reflecting process that has made me be aware of so many important things that I didn't use to think before, and to give little importance to some others I was obsessed with, and that now I know they are insignificant.

(Oso pozik nago eskolan izan dudan practicum esperientziarekin. Baina, baita lehenago bururatu ere egin ez zitzaidan horrenbeste alderdi garrantzitsuz ohartarazi didan eta obsesionatzen ninduten beste hainbati garrantzi txikiago ematen erakutsi didan hausnarketa prozesu honekin ere, orain badakit txikikeriak zirela.)

Jardueren aztarnetan ikus daitekeenez, Practicuma da benetan ezagutza pedagogiko-didaktikoak praktikan jartzean sortzen diren korapiloak behatzeko garaia. Tutoreek ñabarduraz ebaluatu eta harreman pedagogikoa hobetzeko norabide argiak zehazten dituzte.

Hurrengo adibidean ikus dezakegunez, Gurutzek iradokizunak egiten ditu prestakuntzaren mugez oharrarazteaz gain. Bere burua irakaslearen 
parekide gisa aurkezten du, irakaskuntzan ekiteko modu ugari dagoela azpimarratuz.

Gurutze. 2013-2014. Euskara, Hezkuntzarako Tresna. PIIIko txostena

(19. or.): «Beraz, gehien nabarmenduko nukeena hori da hain zuzen, hots, irakasle izateko ikasten gaudenok klaseak nola egituratzearen inguruko praktika gehiago behar ditugula. Hori egiteko bi aukera proposatzen ditut: batetik, ikasgaiak arloko ezagutzetan hainbeste zentratu ordez, didaktika gehiago lantzea; eta bestetik, practicum gehiago egitea edota luzeagoak, ikasturte bateko egitura benetan nolakoa den ikusi ahal izateko».

\subsection{Hizkuntzaren irakaskuntzaz}

\subsubsection{Hizkuntzaren didaktikaren inguruan}

PIIIko lanean eta GRALean hizkuntzaren didaktikarekin lotutako gaiek garrantzi berezia dute, prestakuntza alor horretan ari baikara. Jakintza esparru horren objektuak eta mugak ez dira beti berdin ulertzen hasiberrien artean. Batzuetan, gaizki-ulertuak sortu dira hizkuntzaren didaktikaren objektua fokalizatzean edo, arlo didaktikoa alboratuz, analisia, soilik hizkuntzara mugatu da; arretagunea ikastetxearen eta ikasle taldearen azterketa soziolinguistikoa izan da. Hau, batez ere, euskara espezialitateko ikasleen artean gertatu da. Azterketa sakonagoa eskatuko luke portaera horren analisiak. Arrazoia hauxe izan liteke: azken urteotan euskara, irakaskuntzaren hizkuntza nagusi moduan zabaldu da eta, zenbait irakaslegaik ondorioztatu du euskararen irakaskuntzak ez duela trataera didaktiko berezirik behar eredu eleaniztunen hedapena dela eta.

\subsubsection{Jarduera tipo bat: irakaslearen ahozko azalpenak}

Hizkuntzaren Didaktikaren alorrean, hainbat jarduera-tipo azaltzen dira bildu dugun corpusean, irakasle hasiberrien jardueretako saiakeretan nabarmentzen direnak; horietako bat irakaslearen ahozko azalpenak dira, besteak beste kontsignak ematen ditueneko sekuentziak.

Hainbat ikaslek adierazten du zein zaila gertatzen zaien haurrei azalpenak ematea jarduera bat proposatzerakoan. Ahoskera izaten dute aipagai zenbaitetan: poliki hitz egitea, «irakaslearen hizkera», erabilitako hizkuntza zailegia edo konplexuegia izan dela ohartzea (garrantzi berezia izango du alderdi honek atzerriko hizkuntzan, adibidez). Hasiberriek azpimarratzen dute hizketaldi luzeegiak egiten dituztela eta guztiaren kontrola izan beharra dutela; ikasleenganako arreta ere hobetu beharreko zerbait dela antzematen dute. 
Irakaskuntzan lehen urratsak ematen dituztenerako, badute hainbat ideia ikasketetan zehar unibertsitateko irakasleek preskribitutako eta haiek ere autopreskribitutako irakaskuntzaren inguruan eta, baita ere, berenganatu dituzte jarduera tipo jakin baten prozedurak, egiteko moduak eta hauei buruzko zenbait ezagutza. Hala ere, konturatzen dira uste zutenaren eta benetan ikasgeletan gertatzen denaren arteko aldea handia dela, zituzten ezagutzak mugatuak zirela. Gure azterketaren fokua, errealitatea nola bizi duten horretan datza, prestatu zutenaren eta gertatu denaren arteko aldean. Haien aurreustea ideala da eta ez du errealitatearekin zerikusi handirik.

Adibideetan ikus daitekeenez, jardueraren aurrez aurreko elkarrizketa horietan ikasleek adierazten dute zein konplexu gertatu zaien zenbaitetan aldez aurretik prestatu dutena praktikan jartzea.

Norbere jarduera ikusterakoan; ohartzen dira emaitzak espero zuenari erantzuten ote dion edo ez; hori onuragarria gertatzen da irakasle-prestakuntza prozesurako.

Maitane. 2014-2015. Atzerriko Hizkuntza. Autobeaketa

(12:43): M: Oso oso zaila egiten zitzaiten ariketa bat esplikatzea [...] instrukzioak ematea, hori da [...] nik ikusten baldin baet azalpenak ematen ari naizela, gainera euskeraz ari zaizkitela hitzeiten, eta ikusteitut atzeko ikasliak ez zaizkitela ai kasorik egiten eta gero azkenian esplikazio bat ematen tardatzen det hamar minutu eta gero mahairiz mahai jun behar baet esplikazio berdina ematea...

(25:32): Nik ustet behin bakarrik esan, eta gero ez baldin badue ulertzen, ez esplikau berriz [...] nik ustet baten batek aituko ziala [...] nik hori ingo nuke.

\section{Maddi. 2014-2015. Atzerriko Hizkuntza. Autobehaketa}

(7:27): M: ... eske ez nekin nola esplikatu, nahi nun esplikatu ondo, baino ez nekin nola esplikatu, hola papelak, igual egin behar nuna zan papelak arbelan jarri, ze kostatzen zaie pixkat (ikertzaileak bere hizkeraren erritmo eta abiadura aldaketaz ohartzen du) eske nahi nun gauzak garbi ulertzea baino halere, hola hitzeinda ere, ez dakit batzuk ulertu zuen...

(15:25): M: Eta hau in behar nun aurretikan, klasea hasi aurretik azaldu nola zan estruktura eta erantzunak ere bai. 
Gurutze. 2013-2014. Euskara, Hezkuntzarako Tresna. Autobehaketa

(31:18): G: Neri baliagarria egin zait neri ikasle batek azalpen berdina bere hitzetan ematea [...] txikia zeanean gure arteko hizketa ez da irakaslearen berdina.

Azken kasu honetan, irakasle hasiberriarengan hausnarketaren bilakaera hautematen da. Ikasleen ulermena da bere ardura, eta bere burua, eskola-ume zen garaian kokatzen du, gaur egun nola kudeatuko lukeen erabakitzeko.

Irakasle hasiberriak berak zerbait nola egin duten ohartzen badira eta nola egin zezaketen edo nola hobetu lezaketen ondorioztatzen badute, ikasketa horrek iraun egiten du etorkizunean.

Maitane. 2014-2015. Atzerriko Hizkuntza. GRAL.

(15. or.) Once a simple and logical instruction has been given, teachers have to ensure that students have understood what they have to do. After that, students need to feel that they are able to complete the exercises on their own, being helped by their group-mates.

(Azalpen sinple eta logikoa ematen denean, irakasleek ziurtatu behar dute ikasleek ulertu dutela zer egin behar duten, ondoren, ikasleek sentitu behar dute jarduera egiteko gai direla bakarrik edo ikaskideen laguntzaz.)

Maitane. 2014-2015. Atzerriko Hizkuntza.Egunerokoa

(12. or.) I realized that children don't need to understand everything and that we have to risk and give them as much as information we can.

(Konturatu naiz, ikasleek ez dutela dena ulertu beharrik eta guk arriskua hartu behar dugula ahal dugun informazio guztia emanez.)

(15. or.) You can make interesting a topic to children which is not so attractive for them. The thing is how you work on them and make it interesting with dynamic activities.

(Ikasleentzat gai bat interesgarri bihurtu dezakegu nahiz eta ez izan. Gauza da nola lantzen den eta interesgarri bihurtu jarduera dinamikoen bidez.) 
Hasiberriek, jadanik, beren burua irakasle-rolean ikusten dute agentibitateari dagokionez (guk-irakasleok).

Gurutze. 2013-2014. Euskara, Hezkuntzarako Tresna. GRAL.

(13 or.) Nire jokabidea bideoz aztertzean autokritikoki ikusten dut ikasleen hizketa kudeatzea zaila egin zaidala, baina zeregin horrek beste zenbait alderdi ditu bere interpretazioan: ume berritsuek ume isilen espazioa jan egiten dutela gelditu gabe (...). Egite agresibo horren maiztasuna eta indarra irudikatuz eskua altxatzeko keinua erabiltzen dut (...) besteak beste.

Hasiera batetik partaidetza orekatua nahi nuen, denon aldetik berdina izatea, baina ez dut guztiz lortzen. Hipotetizatzen dut (beharbada) izan daitekeela hasieratik ez ditudalako gauzak ongi egin eta bestetik ez dizkiedala ikasleei gauzak argi utzi:

(...)

Bestalde, egiten dudan beste hausnarketako bat da, azkarregi hitz egiten dudala, ikasleek duten adinera ez dudala egokitu nire hizkera erritmoa (...) eta, horretaz saioa bideoan ikusita konturatu naiz, hau da, kasu hauetan esplizituki adierazten dut bideo baliabideari esker jabetu naizela erabiltzen dudan berbaldiaren erritmo azkarregiaz.

Ikaslea parte hartzera bultzatuko duen beste faktoreetako bat irakaslearen ahotsa da, hark darabilen ahots tonua. Ohartu naiz ahotsa irakaslearen tresna garrantzitsuenetako bat dela, ikasleentzat eredugarria izan behar duena.

\section{PRACTICUMA, IRAKASLEEN PRESTAKUNTZAREN GILTZARRI}

Artikulu honetan, irakasle hasiberriaren prestakuntza bera garatzea eta ibilbide hori aztertzea helburu dituen prestakuntza-ikerketa baten berri eman dugu.

Ikerketa kualitatibo hau mugatua da eta ondorioak ezin dira orokortu. Hala ere, lau ikasleren adibideak beste hainbaten adierazgarri dira eta azaleratu diren hainbat ondorio baliagarri gerta daitezke modu honetako prestakuntzak planifikatzeko.

Gure behaketetan azaldu da hasiberriak Practicumaren garaian eskola-saioak baldintza egokietan eta ariketa ugaritan egiteko aukera izateak nolako garrantzia duen. Hori, ordea, ez da nahikoa. Norbere nahiz kidearen jarduera aztertzeak, lanean ekiteko moduak astindu, aberastu eta garatu egiten ditu eta, honela, Practicumaren konpetentziak lortzeko bidean 
jartzen dira ikasleak, izan ere, «PIIIko ikasleak ikerketarako gaitasuna ere adierazi beharko luke, ondoren burutu beharko dituen azterketa sakonagoak egiteko gai izan dadin. Beraz, ikasleak Practicum III honen bidez eskuratu beharreko gaitasun nagusia da heziketa prozesua bizitzea eta prozesu honekin zerikusia duen ororen inguruan gogoeta egitea» (Ormazuri et al., 2013). Jardueraren aurrez aurreko elkarrizketa edo autobehaketari esker, irakasgaien programetan maiz agertzen ez diren alderdi zehatzak aztertzen dira (ikastetxeko ikasleen jarduna noiz eten zuzenketak egiteko, nola egin eta abar); diskurtsoan, jarduera tipifikatuz, horren esanahiak sakondu eta ekiteko modu berriak irudikatzen dira. Irakasle hasiberriari eskola-saioan egin duena beste ikuspegi batetik behatzeko aukera ematen dio metodologia honek, eta, ondorioz, badirudi, Practicumaren esperientzia areagotu egin daitekeela, ikaskuntza sustatuz eta etorkizunean nola jokatu hausnartzeko baliabideak eskainiz, hizkuntzaren irakaskuntza hobetzeko, eta, orokorrean, hezkuntza jarduera aberasteko.

Ikerketaren arloan ere, giza jardueraren teorietan oinarrituz eta jardueraren aurrez aurreko elkarrizketa edo autobehaketari esker, irakasle hasiberrien prestakuntza-ibilbidea aztertu ahal da, bertan gertatzen diren prestakuntza fenomenoak behatuz. Hasiberriak aurkitzen dituen zailtasun eta oztopoak, egiten dituen asmaketa eta moldaketak, konpondu behar dituen gatazka eta kontraesanak behatu ditzakegu (adibidez, tutorearen eta hasiberriaren arteko rol banaketaren azterketa). Horrela, edukiak egokitzeko eta aberasteko bide gerta daiteke prestakuntza.

Irakasle hasiberria aditu bilakatzeko gakoak zeintzuk diren atzeman ahal izango genuke haien prestakuntza-prozesuaren jarraipena egin ahal izango balitz une jakin baten sekuentzia isolatuetara mugatu ordez. Horrela, ikertzaileok ondorioztatu ahal izango genuke nola areagotu eta aberastu gure ikasleen irakasle-prestakuntza eta hizkuntza-irakasleen trebakuntzarako eduki berriak deskubritu ahal izango genituzke. Hasiberriek grabaketetan egindako jardueren eta horien inguruko hainbat adierazpenen bilduma gune digital babestu batean izatea prestakuntza inguramendu aberatsa gertatzen da ikasleen prestakuntzarako (ik. Frantzian Neopass@ction plataforma, Leblanc \& Ria, 2014).

Ikerketa honetan azaltzen da, bestetik, zein fenomeno konplexu elkarlotzen dituen hasiberria irakasle aditu bihurtzera daraman ibilbideak: egile ugari eta erakunde ezberdinak, Eskola eta Unibertsitatea, batik bat; erakunde bakoitzak jorratzen dituen ezagutzen eragina; ikertzaileen metodoak eta eskoletako tutoreek hasiberriei eskaintzen dizkieten baldintzak; gelan irakasle rola partekatzeko moduak; gelako kudeaketaren eta eduki didaktikoen arteko loturak eta tirabirak; eskolako ikasleriaren aldarteak eta hasiberriaren eginkizunaz duten ikuspegia, eta abar. Horren guztiaren «amalgama» dugu hasiberriak izango duen esperientzia.

Practicumak, benetan prestatzailea izan dadin, baldintza ugari bete beharko lituzke. Ikuspegi honek, hainbat behar ere azaltzen ditu presta- 
kuntzaren ikerketa jardueraren analisian oinarritzeak dituen emaitzez gain. Prestakuntza metodoa emankorra izateko, beharrezkoa litzateke erakundeen arteko benetako elkarlana. Eskolak eta Unibertsitateak elkarrekin antolatu eta prestatu beharko lukete Practicumaren inguramendua, prestakuntza hitzarmena, hasiberriak irakaskuntza esperientzia egokia izateko gutxienekoak bermatuz. Ikastetxeko tutoreak eta unibertsitateko irakasleak Practicumeko ikaslearekin prestakuntza proiektua eratu beharko lukete, proiektu horretarako baldintzak eskainiz eta zainduz. Ikastetxeak dira irakasleen prestakuntzaren ezinbesteko partaideak eta lehen jasotzaileak. Eginkizun hori Administrazioak zaindu beharra du, ikastetxeetako tutoreen rol garrantzitsua aitortuz eta indartuz, baita ere prestakuntza eskainiz. Gizartean irakaskuntzak duen paper nagusiak eskatzen du erakundeen arteko benetako itun eraginkorra.

\section{ERREFERENTZIAK}

Alonso, Idurre, Azpeitia, Agurtzane, Iriondo, Itziar \& Zulaika, Teresa (2017) Autoconfrontación a la propia actividad de enseñanza. Formación e investigación de la formación. Revista Electrónica Interuniversitaria de Formación del Profesorado (REIFOP).

Blin, Thierry (1999). Phénoménologie de l'action sociale. A partir d'Alfred Schïtz. Paris: L'Harmattan.

Cefaï, Daniel (1994). Type, typicalité, typification. La perspective phénoménologique. In B. Fradin, L. Quéré \& J. Widmer (dir.) L'enquête sur les catégories: De Durkheim à Sacks. (pp. 105-128). Paris: Editions HESS.

Clot, Yves, Faïta, Daniel, Fernandez, Gabriel, Scheller, Livia (2001) Entretiens en autoconfrontation croisée: une méthode en clinique de l'activité. Éducation Permanente n. ${ }^{\circ} 146$ (1), 17-25.

Clot, Yves (2001) Editorial. Éducation Permanente n. ${ }^{\circ} 146$ (1), 7-16.

Duboscq, Julie \& Clot, Yves (2010) L'Autoconfrontation croisée comme instrument d'action au travers du dialogue: objets, adresses et gestes renouvelés. Revue d'anthropologie des connaissances, 2, 255-286.

Durand, Marc (2008). Un programme de recherche technologique en formation des adultes. Une approche énactive de l'activité humaine et l'accompagnement de son apprentissage - développement. Education et Didactique, 2(2), 69-93.

Gaudin, Cyrille \& Chaliès, Sébastien (2012). L'utilisation de la vidéo dans la formation professionnelle des enseignants novices: revue de littérature et zones potentielles d'étude. Revue Française de Pédagogie, 178, 115-130.

Hatch, Thomas \& Grossman, Pam (2009). Learning to Look the Boundaries of Representation. Using Technology to Examine Teaching (Overview for a Digital Exhibition: Learning From the Practice of Teaching). Journal of Teacher Education, 60/1, 78-85.

Leblanc, Serge \& Ria, Luc (2014). Designing the Néopass@ction Platform based on Modeling Beginning Teachers' Activity. Design and Technology Education: An International Journal, 19(2). 
Lussi Borer, Valérie, Muller, Alain, Ria, Luc, Saussez, Frédéric, \& Vidal-Gomel, Christine (2014). Conception d'environnements de formation: une entrée par l'analyse de l'activité. Activités, 11(2), 72-75. http://www .activites.org/v11n2/ v11n2.pdfhttp://www .activites.org/v11n2/v11n2.pdf

Lussi Borer, Valérie., Muller, Alain. (2016). Designing a Collaborative Video Learning Lab to Transform Teachers' Work Practices. In P. G. Rossi \& L. Fedeli (Eds.). Integrating Video into Pre-Service and In-Service Teacher Training. IGI Global.

De Montmollin, Maurice (1986). L'intelligence de la tâche, Eléments d'ergonomie cognitive. Berne: Peter Lang.

Ormazuri, Gorka, Zulaika, Teresa, \& Karrera, Inaki, (2013) PRACTICUM III: Eskuliburua. Euskal Herriko Unibertsitateko Argitalpen Zerbitzua.

Picard, Patrick (2014). Former des formateurs pour mieux accompagner les enseignants à faire réussir les élèves: quatre propositions. Ressources du Centre Alain Savary. http://centre-alain-savary.ens-lyon.fr/CAS/education-prioritaire/ former-des-formateurs-pour-mieux-accompagner-les-enseignants-a-fairereussir-les-eleves-quatre-propositions

Plazaola, Itziar \& Stroumza Kim (Eds.) (2007). Paroles de praticiens et description de l'activité. Problématisation méthodologique pour la formation et la recherche, Bruxelles: De Boeck.

Plazaola, Itziar, Ruiz Bikandi, Uri, Aguirre. Ana, Badiola, Nerea, Iriondo, Itziar, Zulaika, Teresa (2013). Irakasle hasiberriaren esperientzia. Ikastaria, 19, 139169.

Plazaola, Itziar \& Iriondo, Itziar (2014). L'expérience d'une enseignante novice en stage: une leçon d'anglais. Educateur, 5, 13-14.

Plazaola, Itziar \& Ozaeta Elorza, Arantza (2014). Les formes de la parole dans l'entretien formatif d'auto-confrontation. Revista electrónica Activités, 11(2), 112-128. http://www .activites.org/v11n2/v11n2.pdfhttp://www.activites.org/ v11n2/v11n2.pdf

Plazaola, Itziar \& Ozaeta Elorza, Arantza (prentsan). Appropriation indigène des méthodes d'analyse de l'activité. In, V. Lussi Borer \& L. Ria (coord.). Apprendre à enseigner. Paris: P.U.F.

Richir, Marc (1988), Relire la « Krisis » de Husserl, Esprit, 140-141, 129-151.

Ricoeur, Paul (1977). La sémantique de l'action. Paris: Editions du Centre de la recherche scientifique.

Ruiz Bikandi, Uri \& Plazaola, Itziar (Eds). (2012). El aula como ámbito de investigación sobre la enseñanza y aprendizaje de la lengua. EHU: Donostia.

Salembier, Pascal, Theureau, Jacques, Zouinar, Moustafa \& Vermersch, Pierre (2001). Action/cognition située et assistance à la coopération, $12^{\mathrm{e}}$ journées francophones d'ingénierie des connaissances IC' 200, 25-27 Juin, Grenoble.

Santagata, Rossella \& Yeh, Cathery. (2015). Characterizing Beginning Teachers' Competence and its Role in Professional Decisions and Practices. ZDM, the International Journal of Mathematics Education, v.7.

Seidel, Tina, Stürmer, Kathleen, Blomberg, Geraldine, Kobarg, Mareike \& Schwindt, Katharina. (2011). Teacher learning from analysis of videotaped classroom situations: Does it make a difference whether teachers observe their own teaching or that of others ? Teaching and Teacher Education, 27(2), 259267. 
Sherin, Miriam G. (2001). Developing a professional vision of classroom events. In T. Wood, B.S. Nelson, \& J. Warfield (Eds.), Beyond classical pedagogy: Teaching elementary school mathematics. Mahwah, NJ: Lawrence Erlbaum.

Suchman, Lucy (1987). Plans and situated actions. The problem of human-machine communication. Cambridge: Cambridge University Press.

Theureau, Jacques (2010). Les entretiens d'autoconfrontation et de remise en situation par les traces matérielles et le programme de recherche «Cours d'action». Revue d'anthropologie des connaissances. Vol 4, n. 2: 287-322.

UPV/EHU. Donostiako Irakasleen Unibertsitate Eskola. GRALaren Gida (2015). [linean] Eskura:http://www.ehu.eus/documents/1582861/2400541/ GRADU+AMAIERAKO + gida+orokorra+150914.pdf [azken kontsulta: 2016-01-20]

Van Es, Elizabeth. A. \& Sherin, Miriam. G. (2008). Mathematics teachers «learning to notice» in the context of a video club. Teaching and Teacher Education, 24, 244-276.

Zulaika, Teresa \& Iriondo, Itziar (2015). Formación del profesorado novel de lenguas: análisis de la propia actividad. In N. Ibarra, J. Ballester, ML. Carrió \& F. Romero (Eds.). Retos en la adquisición de las literaturas y de las lenguas en la era digital. (pp. 591-594). Editorial Universitat Politècnica de València.

\section{Eranskin 1. JARDUERA AZTERTZEKO GALBAHEA: EKINTZA ENUNTZIATUAK}

\section{Jardueraren identifikazioa}

Zein jardueraz ari diren: grabaketan ageri denaz edo/eta erreferentzia gisa hartu duen beste batez: egileak eginiko besteren bat, hasiberrienak (kolektiboarena); ikastetxean egin ohi direnak, preskripzioek diotena, eta abar.

(Ezaugarri honek aditzera emango digu batetik, jarduera tipoa bera eta, bestetik tipikalitatea: zein diren egilearentzat/kolektiboarentzat erreferentzia jarduerak; zein den jarduera paradigma eta nola kokatzen diren jarduera hauek elkarrekin.)

\section{Enuntziazio ainguraketa}

Azaltzen den jarduera edo jardueraren elementua zein denbora-lekutan dagoen enuntziazio momentuarekiko edo beste erreferentzia puntu batekiko: aurretik; jardueran bertan; ondoren, adib. elkarrizketan ainguratua. Lokailuak eta aditz denborak dira adierazle linguistiko nagusiak. 


\section{Jardueraren bilakaeraren deskribapena}

- Jardueraren moldaketa. Aurrez prestatua ote den; zein jarduera tipo; zein sekuentzia, egitura, fase, adierazten dituen.

- Agentibitate muina. Agentibitatearen adierazleak. Nork - nori, norekin, norentzat - egina den jarduera.

- Irakaslearen beraren eta ikaslearen eduki mental eta emozionalak: jarduerari buruzko intentzio, asmo, desio, beldur, kezkak... Ekintza aditzei lotutako beste aditz lexema eta modalizazioek adierazten dituzte [baieztatze sinplea (25 minutu edo bai pasatu zituzten jolasten); nahia (nahi nun pixkat bokabularixue aurreratzie); ustea (suposatzen non bestiek e saiauko ziala bilatzen); beharra].

- Jarduera inguramenduaren aldarteak: egoera fisiko nahiz sinbolikoko baldintzak (denbora, taldearen egoera, materiala, metodoak, eta abar).

- Irakaslearen intentzio eta motibazioak: jardueraren kokapena programan, eduki didaktiko nahiz pedagogikoa.

\section{Eginikoaren balorazioak}

Balorazio positiboa (Ba+), negatiboa (Ba-) edo zalantzazkoa (Ba?) eta honelakoetan zein den arrazoia: ikaslea, ikas-inguramendua, eta abar.

Balorazioaren irizpideak (sinesmen, balio, arau edo gustuen arabera): zertan, zergatik den eta atera den jarduera jakin bat: ondo, eskas, desegoki, zail, eta abar.

\section{Beste azalpen batzuk}

Ofizioko eztabaidak, jardueraren kontaketa zaindua, jardueraren mugak/oztopoak... 